\title{
From Community to Public Libraries: Liberalism, Education, and Self-Government
}

\begin{abstract}
This chapter considers the emergence of public libraries in the southern colonies, looking at how access to knowledge, education, and book provision were understood. It focuses primarily on the various meanings attaching to the word 'public' in the nineteenth century and on the development of 'national' acquisition and collection policies, but it also examines the motivations and catalysts for the development of public libraries more generally, concentrating on the specific, local conditions that led to their establishment and growth, on their connection to political factions concerned with representative government, and on their contribution to a distinctive type of 'colonial modernity'.
\end{abstract}

Keywords Liberalism • Education • Access • Self-government

- Colonial modernity

When, in 1855, Melbourne Punch lampooned the soon-to-open MPL for forming a collection of books so valuable and arcane it would seemingly need to be safeguarded from ordinary 'common' readers (Fig. 2.1), ${ }^{1}$ the idea of a freely accessible library open to all adult members of the public and paid for by local taxation was still a novel one. Rooted in the principles of self-improvement, rational recreation, and utilitarian thought that underpinned nineteenth-century liberalism, the public library was introduced as a legal entity in Britain and Ireland by the Public Libraries Acts of

(C) The Author(s) 2019

L. Atkin et al., Early Public Libraries and Colonial Citizenship

in the British Southern Hemisphere, New Directions in Book History, https://doi.org/10.1007/978-3-030-20426-6_2 


\section{USES OF A PUBLIC LIBRARY.}

I. To be packed in close cases and kept in store for at least a year. This is essential to prevent the books from sustaining the injury which might accrue from exposure on shelves, to the dust of summer or the damp of winter.

II. To be ultimately disposed as far from the centre of population as possible. It is well known that many readers, especially those who have not libraries of their owh, and therefore need to use public reading rooms, are very careless of books.

III. Many books which are essential to studious men, contain matter which it is not desirable for various reasons to put into the hands of the general reader. It is therefore highly judicious on the part of the trustees, to obviate this danger by keeping the library out of sight, until they can make arrangements for placing it beyond the reach of the mere lounger.

Fig. 2.1 'Uses of a Public Library', Melbourne Punch, August 2, 1855, 153. Courtesy of Trove: https://trove.nla.gov.au/newspaper/article/171430414

1850 and 1853, and the establishment of state-supported free public libraries in the southern colonies was closely associated with this new emblem of 'liberal, democratic citizenship'. 'Agitating for the establishment of a public library in South Australia, the Adelaide Observer pointed out in 1853 that 'the principle of instituting public libraries, supported by taxation is one that is being extensively acted upon in the mother country'. At the inauguration of the new municipal TPL in 1870 , the then Governor of Tasmania, Charles Du Cane, made the connection between liberal self-improvement and regional public library provision more explicit when he noted that 'in the great towns of England, no better and easier means of aiding that supplemental self-cultivation has been found than by the establishment of Public Libraries'.

The extent to which the self-improving discourses of nineteenthcentury liberalism formed part of a global (and globalising) ideology has been increasingly acknowledged, ${ }^{5}$ but contrary to the views of the Adelaide Observer the progress of rate-supported municipal libraries in Britain and Ireland was, in fact, slow. By 1868, just 27 local authorities had adopted the public library legislation in Britain; by 1886 , the number was $125 .{ }^{6}$ The early development of municipal public libraries in the southern colonies was even more protracted. By the 1870 s, there was a strong sense that 
volunteerism had failed in the Straits Settlements, but legislation providing for municipal libraries did not appear until the 1950s. ${ }^{7}$ Under legislation enacted between 1869 and 1877, the model promoted and supported by the government in colonial New Zealand remained a user-pays subscription model. ${ }^{8}$ In the Cape Colony, the system of government grants established by the Molteno Regulations of 1874 slowly but unevenly led to an expansion in the number and size of public libraries. ${ }^{9}$ After 1870 , the number of municipal public libraries in colonial Australia rose substantially because of legislation such as the New South Wales Municipalities Act of 1867 and the Victorian Education Act of $1872 .{ }^{10}$ By the time of the federation of the Australian colonies in 1901, there were 407 libraries across the nation either fully supported or subsidised by public funds. ${ }^{11}$

Debates over the public function of these and other colonial libraries were primarily articulated through a vigilant local press. In the Cape Colony, the colonial press was critical in giving political shape, and voice, to the dynamic array of propertied settler groups that Kirsten MacKenzie terms the 'colonial public sphere', ${ }^{12}$ and the press performed a similar role in the cultural sphere across the southern colonies. Some institutions, such as the SAI, routinely had extensive reports of the proceedings of their general meetings published in the press; others, such as the notoriously elitist ASL, tended to receive press attention only in times of controversy. The press could even play a direct role in facilitating the emergence of some institutions, and the demise of others. The SL, the subscription-based library which replaced the earlier Singapore Institution Library, was established after a lengthy article in the Singapore Free Press and Mercantile Advertiser noted 'the want of a really good and proper Public Library' in Singapore, and outlined a plan for such an institution. ${ }^{13}$ While colonial newspaper editors frequently had their own political agendas - and newspaper reports about the use and misuse of colonial libraries must therefore be approached with a degree of caution-local newspapers were influential agents in the evolution of colonial public libraries, contributing both to controversies over what manner of institution they were, and what sort of 'public' they should be serving.

\section{Liberal Vocabularies: The Meanings of 'Public' In THe SOUTHERn COLONIES}

During their evolution in the latter half of the nineteenth century, colonial municipal libraries co-existed and sometimes competed with commercial and community libraries with less clear-cut claims to public status. In the Cape Colony and Natal, 39 subscription libraries were established between 
1818 and $1873,{ }^{14}$ while in colonial New Zealand, some 263 subscription libraries were founded from 1840 to 1873 , and another 506 between 1875 and $1914 .{ }^{15}$ In the Straits Settlements, there were little more than a dozen British-run subscription libraries by the mid-nineteenth century. ${ }^{16}$ In Australia, circulating and subscription libraries, while plentiful and significant, were gradually supplanted in importance from the 1830 s onwards by the libraries attached to mechanics' institutes and related institutions, of which there were nearly 2000 by the end of the century. ${ }^{17}$ If these figures are smaller than those of American and British national networks of community libraries, ${ }^{18}$ by the end of the century colonial Australia, New Zealand, and South Africa had unprecedentedly high densities of community libraries and mechanics' institutes relative to population. ${ }^{19}$

Prior to the British Public Libraries Acts, ideas about what might constitute a public library in the southern colonies varied widely. In the early period of colonisation, the term was often used to describe proprietary libraries which merely inhabited a public space. In 1823, for example, an advertisement was placed in the Hobart Town Gazette for a librarian 'competent to conduct a Public Library and Reading Room', adding that if the candidate was 'possessed of sufficient property to take a share in the concern, perhaps it might be more interesting \& mutual to both parties' ${ }^{20}$ The subscription library model, dependent as it was on collective middleclass initiative, sociability, and investment, ${ }^{21}$ lent itself more easily to the public designation than those purely commercial initiatives run by individual booksellers or auctioneers, since such libraries were often the shared or 'public' property of the denizens of the bourgeois public sphere. When the SAPL was converted from a free library to a subscription library in 1829 , for instance, the government announced its decision 'to abandon all claim, interference, and future pecuniary succour to the library, and ... declared it a Public property', ${ }^{22}$ reflecting a broader political shift in the Cape Colony towards institutions that served the interests of an increasingly assertive mercantile middle-class elite. ${ }^{23}$

While subscription libraries in the southern colonies have appeared to modern eyes as 'inward-looking, classbound, and isolationist', ${ }^{24}$ they can nonetheless be described as 'semi-public' institutions, in that they frequently sought small government grants and/or provided free-to-access reading rooms. As Joanna Innes has succinctly put it, such libraries often felt themselves to have a 'public function' and a 'mission to serve variously conceived publics'. ${ }^{25}$ Originally founded to provide educational opportunities to the working classes, mechanics' institutes acted as de facto 
regional public libraries in colonial Australia and New Zealand. Well before the establishment of the SAI in 1856, the SALMI petitioned the government for a grant for a building, claiming in June 1848 that it was 'a public institution, adapted to the wants of the Colonists, and therefore a public benefit'. ${ }^{26}$ In 1865, the Bendigo Advertiser noted the close connection between public libraries and those 'kindred institutions' doing public good: 'the Melbourne Public Library ... in soliciting for herself [should] not forget that she has morally, if not in law, a family to provide for too' ${ }^{27}$ The SAI was more consciously familial, providing a centralised body to which suburban and regional mechanics' institutes were affiliated, a fact lauded in the Adelaide press with favourable comparisons to the union of mechanics' institutes in Yorkshire. ${ }^{28}$

The sense that private proprietors, subscribers, and donors were 'public benefactors' evincing a 'public spirit' and providing a 'public service' was also evident in the discourses surrounding agitation for the SL and RLM, both of which had relatively inclusive access policies and a variety of subscription rates in order to boost their status as public institutions. ${ }^{29} \mathrm{In}$ contrast, despite employing a rhetoric of its public significance, the ASL's library committee maintained a deliberately narrow view of the public it was required to serve. When the Colonial Office allowed the sum of $£ 10,000$ for the construction of a public library and museum in Sydney (the same amount that would be allowed for the construction of the MPL a decade later), the ASL committee refused to compromise with Governor Sir George Gipps over his requirement to provide a reading room open to the public, opting instead to construct its own privately-funded edifice, at ruinous expense. The New South Wales government would eventually acquire the ASL building and its collection of books at bargain prices for public use as the Sydney FPL. ${ }^{30}$

\section{'Liberality of Access': Reconfiguring Books in the Colonial Public Space}

As the controversy over a public reading room at the ASL suggests, debates over the extent to which access to collections should be restricted to subscribers or open to the general public point to the leading role that colonial public libraries played in the 'democratisation of knowledge' that took place throughout the Anglosphere world during the nineteenth century. As Wallace Kirsop has pointed out, the 'push towards greater openness' in the evolution of colonial public libraries 'was not accidental', and was 
related both to a 'public demand for readier access to books', and to a global network of institutions and settlements that 'stimulated a spirit of emulation'. ${ }^{31}$ Debating the admission policies of the SALMI at an annual general meeting in 1848, for example, the question was asked 'whether that Society was for a class, or for the people? Whether it was a Private Society, or a Public Institution?'. Most members agreed that there should be few restrictions to admission, and that 'respectable' men of the 'lower classes' and 'working men' should be admitted to the institution, but concluded that any institution that charged members $£ 1$ per annum to access its books could not rightly be called a 'public institution', thereby pointing to free access as a key criterion for a public library. ${ }^{32}$

A second emerging criterion for the status of a public library was that of universal access by all social classes without any forms of recommendation or patronage. The SAPL, for example, was open to all male citizens over the age of 18 from its establishment in 1818. Even after its transition to a subscription-based funding model in the late $1820 \mathrm{~s}$, it continued to advertise the availability of its reference collections to 'every class of society': 'no introduction, no recommendation, no securities are required'. ${ }^{33}$ Much later in the century, the MPL committee outlined that institution's particularly liberal philosophy, stating in 1861 that it had decided 'to adopt a greater freedom of access and liberality of access to the books than is usual elsewhere' in order to encourage a 'taste for study'. ${ }^{34}$ The major concession offered by the MPL, which certainly marked it out from libraries 'elsewhere', was the fact that the library allowed readers unfettered access to its shelves, without any need for a reader's ticket or other form of permission or supervision apart from the signing of a visitor's book.

The liberality of access provided by the SAPL and the MPL was not generally practised in British research libraries during the nineteenth century. As David McVilly notes, visitors to the MPL were 'amazed by the numbers using the library and also by the lack of restrictions placed on them'. ${ }^{35}$ Unsupervised public access to shelves was an innovation that remained controversial in Britain for much of the nineteenth century. When Redmond Barry, the guiding figure in the foundation of the MPL and its early development, noted it as an important feature of the institution at the London Congress of Librarians in 1877, the assistant librarian of Cambridge University Library mocked Barry's view that such freedom was 'a right that belonged to the public': 'it was that, in the same sense that it was the idler's right to stroll about for no purpose and doing nothing'. ${ }^{36}$ This was not the only aspect of the MPL's liberal admissions policy to 
attract negative attention from British librarians. At the same conference, Barry was also forced to defend the MPL's policy of admitting readers from the age of 14 , somewhat facetiously championing the reading rights of the rising generation by stating that 'if it were necessary to deprive people of seven years' reading, it would be better to strike off the seven years at the other end, and disqualify people at sixty-three'. ${ }^{37}$

While nearly all the early public libraries freely admitted readers to reading rooms after verifying their identity and address, the MPL was unusual in providing extended opening hours from the outset, being open every day except Sunday from 10 am to $10 \mathrm{pm}$. The SAPL was open for the more modest hours of $10 \mathrm{am}$ to $5 \mathrm{pm}$ in summer and $10 \mathrm{am}$ to $4.30 \mathrm{pm}$ in winter (Sundays and holidays excepted) with limited issuing hours. In 1848, the suggestion of evening opening hours was refused due to a lack of funds. ${ }^{38}$ The SL's original opening hours $(6$ am to $9 \mathrm{pm})$ reflected the idea that people might come to read after working hours, but by 1849 these hours were reduced from 10.30 am to $5.30 \mathrm{pm} .{ }^{39}$ The RLM was similarly open from 10 am to $6 \mathrm{pm}$ except on Sundays. ${ }^{40}$ In the 1830s and 1840s, the ASL's subscription-only reading room was open daily (including Sundays) from 10 am to $5 \mathrm{pm}$, and again from $7 \mathrm{pm}$ to $11 \mathrm{pm}$. By 1853, it was open from 9 am to $9 \mathrm{pm}^{41}$ When its successor, the FPL, opened in 1869, its equally liberal opening hours were from 10 am to $10 \mathrm{pm} .{ }^{42}$ The subscription TPL opened in 1849 with the relatively modest hours of 12 am to $6 \mathrm{pm}$, gradually increasing its hours in the $1850 \mathrm{~s} .{ }^{43}$ When the TPL opened as a municipal library in 1870 , it opened every day from 10 am to $1 \mathrm{pm}$, $3 \mathrm{pm}$ to $6 \mathrm{pm}$, and 7 pm until $9 \mathrm{pm}$, including Sundays. ${ }^{44}$ Despite its retention of a membership and subscription fee, the SAI also steadily increased its accessibility over the second half of the century, being open daily (except Sundays) from $12 \mathrm{pm}$ to $10 \mathrm{pm}$. In 1869, it opened on holiday periods, except Christmas Day and Good Friday. In 1879, it opened on Sundays. ${ }^{45}$

Opening libraries on Sundays and holidays was controversial and often involved arbitrating between secular and religious communities. The former saw the moral and civic benefits of Sunday opening, especially for the working classes who often could not access the library on any other day, and for children between the ages of 12 and 16 (who were usually excluded from early public libraries). Others saw weekend opening hours as contributing to the break-down of domesticity and the nuclear family. As Melbourne Punch's satirical Mrs. Sarah Grundy pointed out in an 1859 article on " "Social Institutions" and "Evils" in General, and "Public Libraries", in Particular', the public library could be a means for avoiding the home as 
much as it could be a means of edification. ${ }^{46}$ For this reason, many public libraries promoted the circulating library as a vital part of their modus operandi. In the Cape Colony, for example, the Attorney General William Porter noted the importance of the circulating section of the public library for family reading, a domestic virtue also upheld by the press elsewhere. ${ }^{47}$

While public libraries in the southern colonies generally agreed on the importance of liberal access policies, it was increasingly recognised that the public benefit of free access to books was contingent on the nature of library collections themselves. There was often considerable tension surrounding whether libraries should concentrate on acquiring substantial reference collections, or devote more resources to maintaining collections available for borrowing. Frequently this tension dissolved into familiar arguments over the proportions of 'serious' and 'light' works in the libraries (see Chap. 4), but the sense that a truly 'public' library must account for all types of readers also became a recurring refrain in the southern colonies. As reconceived by Antonio Panizzi during his tenure as Keeper of Printed Books between 1837 and 1856, the BML had attempted to distinguish itself from the 'aristocratic dilettantism' of its original creators by moving to acquire 'common modern books' alongside 'rare, ephemeral, voluminous and costly publications'. ${ }^{48}$

Following Panizzi's distinction between a 'library for education' and a 'library for research', public libraries in the southern colonies were increasingly distinguished from university libraries on the basis both of their rights of access and the kinds of books they stocked. At the laying of the foundation stone of the new South Australian Public Library in 1879, for example, the chairman of the SAI's governing body, Rowland Rees, noted that while the bulk of the library was to 'consist of works of permanent value', the governing body nonetheless proposed 'to provide a library which will meet the requirements of casual readers, as well as those who pursue continuous studies; a place for the deposit of books and the assemblage of readers' ${ }^{49}$ A series of articles in the Melbourne Herald in the 1860s and 1870 s, on the other hand, condemned the MPL for not stocking popular novels-'Milton, Byron, Tennyson, and Swinburne are admitted: why not also Scott, Dickens, Thackeray, and George Eliot?'- and therefore for not meeting the demands of ordinary readers. ${ }^{50}$ For treating books like 'old china', the MPL was accused of being less relevant to the colonial reading public than the 'suburban libraries at Prahran, St Kilda, and Collingwood'. ${ }^{51}$

Legal deposit provisions eventually consolidated the role of public libraries as repositories of all kinds of books, but legal deposit in the colonies did not commence until the 1870s and 1880s, and was not always stringently 
enforced. In 1866, the Book Registration Ordinance in the Straits Settlements required the registration of all books printed in the Straits but did not result in legal deposit. In 1873, the SAPL became the legal deposit library in the Cape Colony. In South Australia and New South Wales, the Copyright Acts of 1878 and 1879, respectively, did the same. Despite the 1869 Copyright Act of Victoria, it was not until the 1880s that the MPL consolidated its status as a legal deposit library. ${ }^{52}$ The strong link in the colonial world between copyright laws and legal deposit suggests that a balance was being sought between the rights of owners, on the one hand, and the users of copyright material, on the other. As the century progressed, this balance was increasingly weighted in favour of the user, promoting the public interest through the encouragement of reading and learning.

\section{A 'habitat but no home': Home Education, Self- Government, and InTra-Colonial Rivalry}

Contemporary reflections on reading, books, and libraries are suggestive of their special importance in colonies as far away from Britain as Singapore, South Africa, and Australia. Noting the high level of government support for libraries in British India, the Singapore Free Press argued in 1843 that it was important for the 'exiled' Briton with no independent 'home politics' to take up reading: 'to provide against our forming inadequate or false conceptions of what takes place at a distance it is clearly necessary that we should have access to books' ${ }^{53}$ While a fear of 'false conceptions' partly explains the colonial desire to 'keep up-to-date' with the latest print and news, and to be 'almost on par with those at home as regards the literature and science of the passing day' ${ }^{54}$ an emerging awareness of the heightened moral importance of reading in the colonies appears in New Zealand Company propaganda in 1833:

none but they who have resided in a new colony can appreciate the value of a new book; and we are happy to bear testimony, that in no colony is literature more appreciated than in New Zealand: as might be expected from the very superior class of men who have migrated to our favourite colony.

If part of this propaganda was to distinguish the free New Zealand settlements from the penal colonies of New South Wales, Van Diemen's Land, and Singapore, there was nonetheless a prevailing sense among colonial communities that good reading encouraged civility: 'a well-conducted colonist is of necessity a reading man' ${ }^{55}$ 
Fear of the effects of isolation and distance from metropolitan seats of knowledge took on a particular importance in the tropical climates of Singapore, Penang, and Malacca, where reading was seen as a counter to fears about physical, mental, and moral degeneration in the tropics, as well as to fears about miscegenation and proximity to 'native' populations. ${ }^{56}$ Comparable arguments about distance, degeneration, and the curative role of reading were also made in relation to those 'wayward' young men that settler colonies were perceived to attract in great numbers. The physician and future Chairman of the RLM committee, Robert Little, argued that a public library in Singapore would be one 'of the greatest safeguards we could find for the young people of the Settlement': 'being able to read an entertaining novel, a well written history, "or an instructive biography," might keep them at home at night and save them from the gaming table'. While the Straits Observer scoffed at Little's claims that a public library could convince young men to 'stop home like good boys', ${ }^{57}$ a similar argument about the need to safeguard the youth of the colony was made in the Cape Colony, with numerous commentators noting the importance of shaping the taste of the young men on whom 'the hope of the Colony' depended.

In 1848, the Chief Justice of the Cape Colony, Sir John Wylde, noted a shift in the demographics of the SAPL's users, facilitated by a new, cheaper subscription rate, from old gentlemen to young professionals. The new subscribers were 'for the most part, young men in public service- or, in attorneys' offices-, or in merchants' counting-houses', in other words, the future administrators of the colony 'advancing to take our places' ${ }^{58} \mathrm{By}$ including lower-middle-class professionals within the library's remit, and investing in them the virtues of 'serious' reading, the SAPL sought to play a central role in shaping the moral and intellectual life of the Cape Colony's future leaders. In 1853, W. A. Newman, the first Dean of Cape Town, likewise stressed the moral role a public library could have in the lives of young colonists far from their places of birth. In referring to these young men of the Cape as having a 'habitat but no home', Newman was referencing the terms of the 1818 proclamation establishing the SAPL, which claimed the purpose of the library was 'to lay the foundation of a system which shall place the means of Knowledge within the reach of the youth of this Colony, and bring within their reach what the most eloquent of ancient writers has considered to be one of the first blessings of life-HOME EDUCATION'. ${ }^{9}$

While Newman does not draw any explicit connections between home education and home rule, other commentary about the SAPL in the lead- 
up to the establishment of representative government (est. 1853) suggests how closely the rhetoric surrounding education was linked to questions of self-governance. In his 1848 speech to SAPL subscribers, James Adamson, Professor of English and Classics at the South African College (est. 1829), made clear the strong link between thriving educational institutions and colonial self-determination:

I feel satisfied that we could have in this colony all the means of educating our youth for every one of the learned professions, if only we set our heart and hand. Unless we do so, we can never flourish as a community,-for without education we are as naught; we act not upon those liberal principles that tend to the advancement of society ... and direct us in the road to that future which we hope to attain. ${ }^{60}$

Adamson's sense of the SAPL as a decisive intervention into the colony's progress towards emerging nation-statehood came increasingly to the fore in 1853. In that year, Governor Harry Smith called for improved education provision at the Cape, citing Nova Scotia as an example of the benefits of universal education and linking the importance of 'serious reading' with the establishment of a legislative assembly. The nation's future law givers, Smith implied, had a moral and civic responsibility to be well cultivated; intellectual seriousness was essential for the colony to be taken seriously as a semi-autonomous nation. ${ }^{61}$

In Victoria, too, the MPL was linked to questions of self-government and the assertion of an independent local identity. The library was one of several rapidly-formed institutions after the separation of the colony of Victoria from New South Wales in 1850, including a new Supreme Court (est. 1853), the University of Melbourne (est. 1853), and Legislative Chambers (est. 1856). ${ }^{62}$ Seeing the MPL as part of a 'cluster' of institutions intended to support the colony's learning, culture, and independence helps us to better understand its significance as an institution intertwined with aspects of colonial self-determination and nation-building. If by 1860 the Cape Colony, New Zealand, and all of the Australian colonies, apart from Western Australia, had been granted either representative or responsible self-government and had their own legislative assemblies, the establishment of a functioning public library was nonetheless acknowledged to be part of a process of intellectual and civic maturity leading up to more decisive acts of self-determination such as Australian Federation and responsible government in the Cape-acts that were entangled with 
questions of intra-colonial rivalry and the issue of relative status within imperial hierarchies. ${ }^{63}$

These rivalries suggest both an awareness of a colony's status within a wider British Empire and more ambitious assertions of colonial intellectual accomplishment. Complaining in 1854 about the lack of public lectures at the SAI, the South Australian Register displayed a keen awareness of developments both inside and outside the Australian colonies: 'for a long time we have been greatly outdone in these matters by the neighbouring colonies of Victoria, New South Wales, and Tasmania. In England ... the leading in the State ... assert the highest places in the temples of literature and science' ${ }^{64}$ Four years later, a letter to the editor in the same newspaper noted the SAI's lack of display space, arguing that the government needed to provide 'more suitable accommodation for books and readers' because 'doubtless this is often referred to with a sneer by our more influential neighbours. We receive specimens from the Cape, from Victoria, from various parts of our own colony, but have no eligible place to house them'. ${ }^{65}$

The SAPL committee similarly argued in 1857 that it was 'not too soon for South Africa' to follow the examples of New South Wales and Canada in establishing public institutions 'when intelligence and commercial prosperity in this colony bid fair to rival an attainment exemplified in the older countries', signalling an intention not just to replicate British institutions but to outdo them. ${ }^{66}$ As early as 1853 , Governor Smith went as far as to describe the SAPL as the preeminent public library in the British world, arguing that in Britain itself there was only one truly public library, Chetham's Library in Manchester, which had only 20,000 volumes to the SAPL's 32,000.$^{67}$ Smith's hyperbole aside, it was acknowledged in Britain both that the state of those libraries open to the general public had fallen behind similar libraries in Europe and America, and that they were inaccessible to the working classes. ${ }^{68}$ It was also recognised that the SAPL 'would stand a comparison with almost any library in England, the national ones excepted'. ${ }^{69}$ The MPL, too, was declared a rival to many of the libraries in the Anglophone world, suggesting the extent to which colonial libraries measured their success on a global scale. As one correspondent to the Melbourne Argus confidently claimed: 'as to the United States libraries, I shall be no less gratified than surprised if, on visiting any one of them, I find in it a collection of books equally valuable with that which Melbourne already boasts, and at the same time equally free from chaff' ${ }^{70}$ 


\section{'Hardly its EQUal IN POINT OF BEAUTY and convenience': Colonial Public Libraries as Agencies of Modernity}

Smith's claim in 1853 that the SAPL was the largest truly public library in the British world reflected the growing sense in both Britain and its colonies that the large research libraries of Britain and continental Europe were only nominally 'public'. As one correspondent to the London Times pointed out in 1841, the BML, with its specialised collections, restricted opening hours and admission policies, and small number of users, was 'a mere sealed book to the million'. ${ }^{71}$ Even after 1850 , when the BML was legally a public library, admission still required a letter of recommendation and a reading card..$^{72}$ Despite modelling itself on the BML, the MPL, with its liberal access policies designed to promote a freer scholarly environment, saw itself working 'against the inroads of that exclusive spirit which has so greatly diminished the usefulness of similar establishments in England'.$^{73}$

While the size of the collections of colonial libraries remained well below those of major British and European libraries, Smith was right to point out that colonial libraries could outstrip metropolitan libraries in terms of rights of access, facilities, and modern technologies. The MPL and the SAI, for example, both enjoyed gas lighting by the $1860 \mathrm{~s}-\mathrm{a}$ full two decades before the BML-and despite its troubled financial circumstances, the ASL also had gas lighting installed in its building from its opening in $1845 .^{74}$ Ventilation in the MPL was technologically advanced, including 'flues carried through the main walls' and 'air tubes leading ... to the roof' ${ }^{75}$ In a letter to his London bookseller, J. J. Guillaume, Redmond Barry was confident that the books in the MPL enjoyed better conditions than those in libraries in London: 'here we enjoy perfect ventilation and absolute freedom from damp, smoke, soot, or the disagreeable atmospheric and climactic annoyances of which in England complaint is made. Gas hitherto has not produced the deleterious effects which have been so destructive in the Athenaeum Library and elsewhere in Europe' ${ }^{76}$ While Barry's optimism regarding the effect of gas on the books in the MPL proved misplaced, his belief that its reading room had 'hardly its equal in point of beauty and convenience either on the European continent or in England' was more well founded. Far from being a poor copy of metropolitan institutions, the reading room was both beautiful and practical, being able to seat up to 650 people, whereas the BML's reading room could seat 450 people in 1861 and in 1862 was reduced to 350 per day. ${ }^{77}$ 
The accelerated modernity of colonial libraries was self-consciously cultivated by nineteenth-century library committees, who not only saw the public library as a symbol of the social mobility and democratic potential of colonial societies, but also as a microcosm of the remarkably intense condensation of the various stages of capitalism and social development that took place in the colonial world. In his address at the opening of the Ballarat Free Public Library in 1869, Barry dismissed the idea that 'Australia has no history', arguing that the inhabitants of Australia had instead bypassed the infant stages of society and 'come into the possession of our estate in the full vigor of matured manhood' ${ }^{78}$ The ability of colonial societies to skip stages of social development and transform themselves into modern societies was aided by the population explosion occasioned by the gold rushes in Australia and New Zealand in the 1850s and 1860s. The total population of all the Australian colonies increased almost fourfold from 430,000 in 1851 to 1.7 million in 1871 , one of the most prominent examples of what James Belich has identified as a series of 'settlement booms' associated with Anglophone expansion throughout the nineteenth century. ${ }^{79}$ Such 'booms' were accompanied by rapid commercial, industrial, and technological development, which enabled an equally rapid development in social and cultural institutions. ${ }^{80}$

At the same time, public and other institutional libraries were positioned as antidotes to the greed of gold rushes and the mercantile nature of colonial societies more generally. An article in the Straits Times in 1846 argued for the need for a public library in Singapore because the settlement was almost 'exclusively mercantile' and 'fully a century behind other settlements' in its cultural development. ${ }^{81}$ David Goodman has argued that libraries and other cultural institutions were similarly 'central to the attempt by elites to reassert order in gold-rush Victoria', where they helped to combat the perceived social malaise symbolised above all by the unsettled, migratory life of the digger. ${ }^{82}$ The grandeur of the MPL, the eminently scholarly nature of its collections, and its prestigious first major catalogue of 1861 provided a highly visible redress to the idea that colonial life was purely self-interested and materialistic. ${ }^{83}$ Similarly, the South Australian Weekly Chronicle referred in 1866 to the importance of the SAI's role in 'cultivating the public taste'. ${ }^{84}$

Colonial public libraries were therefore perceived to be agencies of modernity at the frontier of colonial taste-formation and civic modernisation, both in a material and intellectual sense. This new kind of 'colonial modernity' was self-consciously distinctive from metropolitan modernity, 
not only temporally and spatially but also in its attention to a peculiarly colonial egalitarianism and inventiveness. The committee of the MPL argued, for example, that whereas in England university education 'has tended most banefully' towards 'mere learned accomplishments', the libraries and universities of the colonial world had the opportunity to encourage invention and creativity. ${ }^{85} \mathrm{~A}$ letter to the Melbourne Argus in 1856 entitled 'Books within reach of our "Inventors"' agreed with the MPL committee, noting the use made of available scientific books and periodicals by enterprising patrons. ${ }^{86}$ In 1879, the Governor of South Australia went further in maintaining that a library and museum for the masses should have a technological and industrial department along the lines of the Museum of Industry in Dublin, the Imperial Technical School in Moscow, and the School of Practical Science in Toronto. If his argument was qualified by the claim that 'in an industrial country like South Australia the utilitarian must take priority of the aesthetical' - at least until such time as art could 'take the place in the life of this colony that it has occupied in the past history of older countries, and that it occupies even now in the adjoining province of Victoria'there was nonetheless a sense that in the southern colonies 'inventive genius' was, or could be, 'ever active'. ${ }^{87}$

\section{Building the National Collection: Public Monuments and Local Archives}

While the collections of colonial public libraries provided unique opportunities for both intellectual innovation and a colony's self-promotion, library buildings were among the most important material signifiers of their cultural ambitions. Nearly all of the purpose-built 'landmark' premises housing these major colonial libraries were neo-classical in style, emphasising the importance of the library as a display of cultural capital, as well as being a marker of respectability, and of 'civic identity and proper civic behaviour'. ${ }^{88}$ As the trustees of the SAI remarked in their third annual report, a landmark building would be 'the means by which the Institute will be enabled to step forth from its present character of a mere circulating library on a somewhat liberal footing, and enter on the career of public utility marked out for it by the Legislature' ${ }^{89}$ For this reason, debates about where and how a 'central' and 'national' public library should be built were fierce. ${ }^{90}$

Many of the buildings were modelled on existing buildings in Britain. The SAPL building inaugurated in late 1860, for example, was based on George Basevi's 1845 design for the Fitzwilliam Museum in Cambridge, 


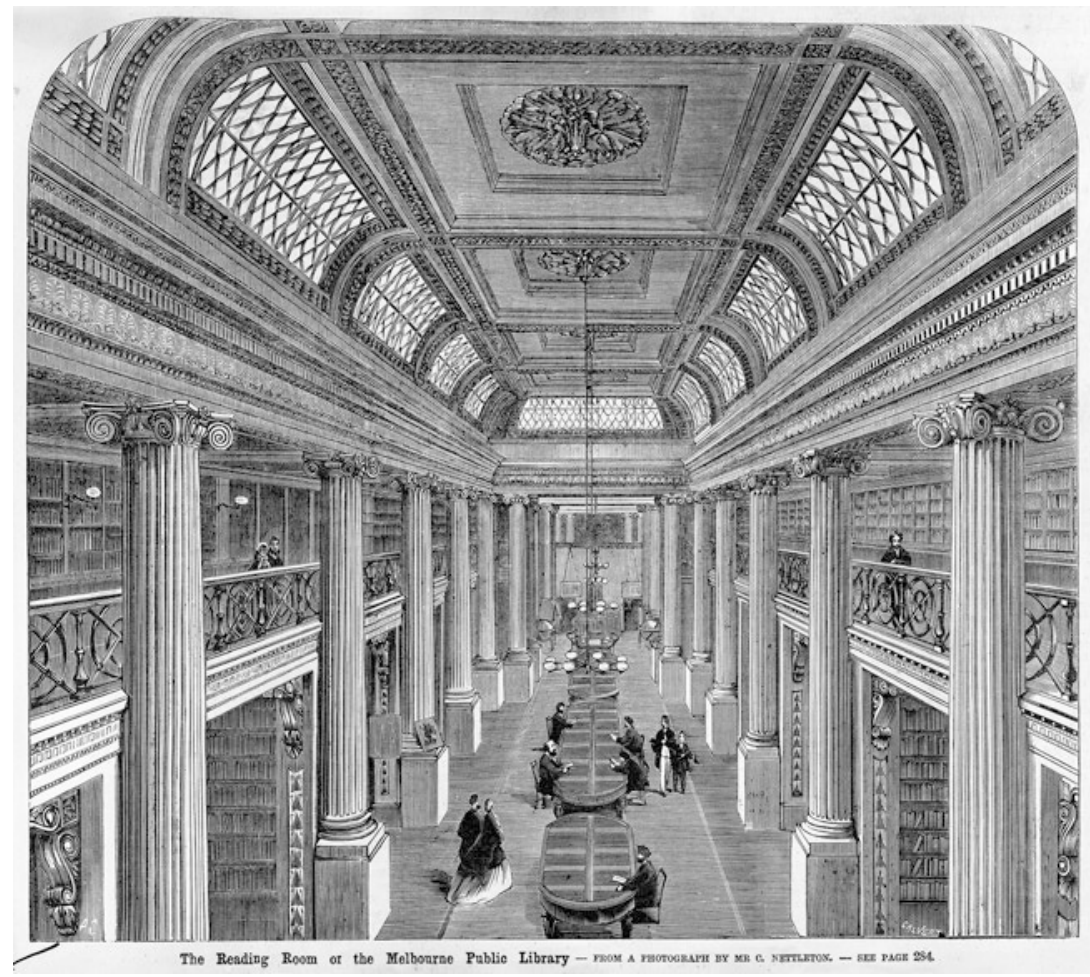

Fig. 2.2 Samuel Calvert, 'The Reading Room of the Melbourne Public Library', wood engraving, Illustrated Melbourne Post, June 27, 1866. Courtesy of the State Library of Victoria: http://handle.slv.vic.gov.au/10381/295506

while the MPL and RLM buildings were neo-Palladian in style. The internal spaces of colonial libraries did not, however, tend to mirror the 'panoptic character' of the BML reading room, with its central structure housing the library's staff. ${ }^{91}$ Instead, gallery-style reading rooms, such as those in the SAI and the MPL, either provided free public access to shelves or allowed books to be visible to the user, reflecting new democratic models of self-surveillance (Fig. 2.2). ${ }^{92}$

That the rotundas, porticos, pantheons, colonnades, and Corinthian columns of these neo-classical structures were meant to symbolise a connection to 'time-honoured cultural values' was made explicit by Redmond Barry when he delivered a lecture to the workmen employed in building 
the Rotunda and Great Hall of the MPL for the Intercolonial Exhibition of 1866. Beginning with a brief history of architecture, ancient and modern, Barry provided a detailed comparative analysis of the scale of the MPL in relation to other important buildings across time and space: 'it is 220 feet long, 82 wide, so that, with the exception of those of Padua, Ypres, and our own Westminster, there is none in Europe enumerated above which exceeds it in length, while it is larger than four of England's cathedrals'.$^{93}$ As these comments suggest, colonial public libraries sought both to harness and to rival the prestige of major institutions abroad, creating 'statements to posterity' associated with rising proto-national sentiments, while also championing a new spirit of democratic openness that challenged the perceived elitism of British metropolitan institutions. ${ }^{94}$ Although colonial public libraries were clearly modelled on British institutions and designed to show allegiance to imperial institutions and ideologies, they were also often equally carefully organised to emphasise national and regional affiliations.

One means of foregrounding nascent 'national' intellectual accomplishment was in the archiving of scholarly material relating to the colonies, and the collection of local print culture more generally. The SAPL was perhaps the most advanced in this regard. Its chief librarian from 1828 to 1844, Alexander Jardine, was an active collector of books in all genres (but especially voyages and travels) about the Cape, and he also collected and archived the products of the Cape presses. In the 1829 SAPL catalogue, there are eight volumes of works from the Cape presses listed, including pamphlets, reports, essays, correspondence, and ordinances, as well as three volumes of papers 'relating to the Cape of Good Hope'. ${ }^{95} \mathrm{By}$ 1842, works printed by the Cape presses include 17 volumes of pamphlets on various topics (written in English and Dutch), as well as copies of all the Cape newspapers and periodicals. ${ }^{96}$ The 1862 catalogue is also notable for being the first to have a classificatory category specifically devoted to books about and from South Africa, as well as including for the first time George Grey's ethnological and philological collections. ${ }^{97}$

Acknowledging the importance of collectors such as Grey, colonial library committees were increasingly aware of their role as archivists of regional knowledge as the nineteenth century progressed, particularly in the fields of philology, ethnography, and natural history (see Chap. 5). The Straits Times argued in 1846 for the importance of studying the antiquities, ethnography, and various tribes of the Malay Archipelago, suggesting that the association of a Literary and Scientific Institution with the library would render it 'more efficient and useful'. ${ }^{8}$ Such an institution, the Straits 
Branch of the Royal Asiatic Society, was eventually established in 1877, an event which coincided with a new catalogue of the RLM with classifications devoted to the philology and ethnography of the Malay Archipelago, as well as to books about and from the Malay world. The 1877 catalogue lists, for example, thirty books under the new classificatory category 'Eastern Archipelago \& Straits Settlements'. ${ }^{99}$

Heather Gaunt has shown that public libraries in colonial Australia, on the other hand, and in contrast to British regional equivalents, were haphazard in their collection of local material. ${ }^{100}$ While the trustees of the SAI noted at their annual general meeting in 1861 that it has always appeared to the Board to be almost a matter of public duty that each of the Australian colonies should possess works so peculiarly devoted to them', ${ }^{101}$ the percentage of local material in colonial libraries was often small. The 1848/1849 catalogue of the SALMI, for example, contains Charles Sturt's Expeditions in Australia (1849) and a small number of texts on various Australian colonies and provinces in its 'Topography and Travels' section, but the library was not seriously collecting local works at this time. By 1869 , its predecessor, the SAI, had a larger proportion of works on the Australian colonies and surrounding regions, as well as a full collection of state papers for the Australian and New Zealand colonies, but its Australiana collection could by no means be considered substantial. ${ }^{102}$

Local collections at the ASL/FPL, MPL, and TPL were similarly limited. The TPL did not substantially develop its Australiana collection until the 1920s and 1930s. ${ }^{103}$ Similarly, the ASL did not collect the productions of the local press, arguing that they were 'neither extensive, expensive nor difficult to obtain'. Its archival function was nonetheless serendipitously amplified by a bequest of nearly 1000 volumes of books, manuscripts, pamphlets, and newspapers from Edward Wise in 1865, as well as by the FPL's librarian R. C. Walker's interest in increasing the library's Australiana holdings from the 1870s onwards. ${ }^{104}$ By the 1890s, the (then) Public Library of New South Wales, under the librarianship of H. C. L. Anderson, had a much more substantial Australasian collection but it was once again significantly bolstered by a magnificent bequest of some 60,000 volumes of early Australian books, pamphlets, and manuscripts, as well as works relating to the Pacific, East Indies, and Antarctica, from David Scott Mitchell in 1907. ${ }^{105}$

For public libraries such as the FPL and the MPL, neglecting local material could be controversial. Even before the period in the latenineteenth century when 'colonial editions' were aggressively marketed to colonial audiences by the metropolitan book trade, ${ }^{106}$ the MPL had to 
repeatedly defend itself against accusations that it was not archiving local and regional colonial productions or supporting the local print industry. According to Charles Gavan Duffy (later a trustee of the library), the MPL contained 'not a single volume on Australian affairs' when it opened to the public in 1856. Duffy accordingly considered the MPL 'strangely unfit for its position in the capital of a new country'. ${ }^{107}$ The Melbourne press tended to concur, with the library gaining a reputation in the $1860 \mathrm{~s}$ and 1870s for acquiring British and European material at the expense of more local and regional material. In 1874, the Herald criticised the library for dedicating too much space to unread and out-of-place classics, citing an Italian edition of Bocaccio, while 'matters relating to Australia are too much ignored'. A few years later, the Austral Review similarly called on the MPL to 'let the Greek Dryasdusts stifle, but not our Australian youth anxious for knowledge of their native land'. By 1879, the Melbourne Age claimed that 'the colonial department is notoriously incomplete and that of our own colony ... the most meagre'. ${ }^{108}$

Although Redmond Barry was indeed concerned to build the library's reputation in certain prestige areas such as Greek and Latin, Shakespeariana, and editions and translations of the Bible, these charges were not entirely fair. McVilly notes that up until 1869 , when the MPL received legal deposit rights, it 'purchased most of the serious works published in Victoria, while not going out of its way to chase fugitive material', as well as purchasing books published in England about the Australian colonies. Even if it was less interested in material emanating from other colonies, the MPL did collect printed works on South Asia from several sources from 1853 to 1880, including from Frederik Muller in Amsterdam and from large London booksellers such as James Bain, Bernard Quaritch, and Henry Sotheran. While acquisitions on British India tended to be based on classical or Orientalist foundations, the collection also included dictionaries, grammars, and readers in modern Indian languages, travels and voyages to India, contemporary periodicals such as the Calcutta Review, and Indian tracts and pamphlets, primarily on modern Indian politics. ${ }^{109}$ Moreover, exchanges of volumes, pamphlets, and maps from India occurred on a large scale from 1870 onwards. ${ }^{110}$

After the MPL's early collection was formed largely through Barry's dealings with the London bookseller Guillaume and other overseas booksellers, a letter to the editor of the Herald newspaper in 1861 asked why 'the grants of money voted to the public library are not expended in this country', and promoted the booksellers of Melbourne as having 'some of the rarest and best known works, as well as the more modern, and good supplies of those 
just published'. ${ }^{111}$ Although the MPL was defended by, among others, the Melbourne bookseller H. T. Dwight, who claimed he had a "'standing order" from the trustees to supply the library with all colonial publications', and the library did indeed purchase books from local booksellers as well as at auctions and from private collections, ${ }^{112}$ critics remained unconvinced by the MPL's support of a nascent Australian print and publishing culture. By the 1880s, ongoing complaints resulted in all non-British periodical publications being purchased through local booksellers, and, after Barry's death, the trustees of the MPL cancelled all standing orders with overseas firms, dramatically reducing European purchases in favour of Melbourne purchases. ${ }^{113}$

While those advocating for public libraries in the southern colonies drew on the globalising rhetoric of liberal metropolitan discourses relating to universal education and self-improvement, they were also driven by particular local or regional imperatives such as the acquisition of local books, the archiving of regional knowledge, and the production of ethnographic field work, as well as by more local questions surrounding colonial self-determination and independence. The importance of studying and collecting local natural history, ethnography, and antiquities, the vast distances from metropolitan cultural institutions and seats of knowledge, the need to educate both British emigrant and Indigenous populations, the perceived dangers of living in the tropics, and the special problems of itinerant diggers and 'wayward youths'-these were all causes for comment and concern in public discourse, and problems for which colonial public libraries were looked to as a potential remedy. In this way, colonial public libraries were both embedded in their local surroundings and formed part of a wider culture of nineteenth-century liberalism in Britain, Europe, and North America, to which they both reacted and contributed.

\section{Notes}

1. 'Uses of a Public Library', Melbourne Punch, August 2, 1855, 153.

2. Patrick Joyce, 'The Politics of the Liberal Archive', History of the Human Sciences 12, no. 2 (1999): 35-49 (35).

3. Adelaide Observer, Supplement, December 3, 1853, 1.

4. Quoted in Heather Gaunt, 'Identity and Nation in the Australian Public Library: The Development of Local and National Collections 1850s-1940s, Using the Tasmanian Public Library as Case Study' (PhD diss., University of Tasmania, 2010), 54, accessed August 8, 2018: https://eprints.utas. edu.au/10772/. 
5. See, for example, Regenia Gagnier, Individualism, Decadence and Globalization. On the Relationship of Part to Whole, 1859-1920 (Basingstoke: Palgrave Macmillan, 2010).

6. Alistair Black, 'The People's University', in The Cambridge History of Libraries in Great Britain and Ireland Volume III 1850-2000, ed. Alistair Black and Peter Hoare (Cambridge: Cambridge University Press, 2006), 24-39 (27).

7. Straits Times Overland Journal (Singapore), December 31, 1874, 3. Edward Lim Huck Tee, Libraries in West Malaysia and Singapore (Kuala Lumpur: University of Malaya Library, 1970), 36.

8. J. E. Traue, 'The Public Library Explosion in Colonial New Zealand', Libraries and the Cultural Record 42, no. 2 (2007): 151-164 (153).

9. Theodorus Friis, The Public Library in South Africa: An Evaluative Study (Cape Town: Afrikaanse Pers-Boekhandel, 1962), 69.

10. David J. Jones, 'Public Library Development in New South Wales', The Australian Library Journal 54, no. 2 (2003): 130-137.

11. Peter Biskup and Doreen Goodman, Australian Libraries, 3rd ed. (London: Clive Bingley, 1982), 81.

12. Kirsten McKenzie, "Franklins of the Cape": The South African Commercial Advertiser and the Creation of a Colonial Public Sphere, 1824-1854', Kronos 25 (1998/1999): 88-102.

13. Singapore Free Press and Mercantile Advertiser, September 21, 1843, 2. R. Hantisch, 'Raffles Library and Museum, Singapore', in One Hundred Years of Singapore, ed. Walter Makepeave, Gilbert Brook, and Roland Braddell, 2 vols (London: John Murray, 1921), 1: 519-566 (526).

14. Jacqueline Audrey Kalley, 'The Effect of Apartheid on the Provision of Public, Provincial and Community Library Services in South Africa with Particular Reference to the Transval' (PhD Diss., University of Natal, 1994), 15.

15. Traue, 'The Public Library Explosion', 152.

16. Tee, Libraries in West Malaysia, 11-15.

17. Derek A. Whitelock, The Great Tradition: A History of Adult Education in Australia (St Lucia, Qld: University of Queensland Press, 1974), 127. Philip Candy, "The Light of Heaven Itself": The Contribution of the Institutes to Australia's Cultural History', in Pioneering Culture: Mechanics Institutes and Schools of Art in Australia, ed. P. C. Candy and J. Laurent (Adelaide: Auslib Press, 1994), 1-28 (2).

18. For US statistics, see Wayne A. Wiegand, Part of our Lives: A People's History of the American Public Library (Oxford: Oxford University Press, 2015), 12, 48-49.

19. Traue, 'The Public Library Explosion', 158.

20. Hobart Town Gazette, February 15, 1823, 2. 
21. James Raven, 'The Advance of the Subscription Library', in Cambridge History of Libraries in Britain and Ireland Volume II 1640-1850, ed. Giles Mandelbrote and K. A. Manley (Cambridge: Cambridge University Press, 2006), 239-263.

22. Catalogue, SAPL, 1831, 8: http://www.ucd.ie/southhem/record. html\#265.

23. Saul Dubow, The Commonwealth of Knowledge: Science, Sensibility, and White South Africa, 1820-2000 (Oxford: Oxford University Press, 2006).

24. John Levett, 'The Tasmanian Public Library 1849-1869: The Rise and Fall of a Colonial Institution' (Masters Thesis, Monash University, 1984), 79.

25. Joanna Innes, 'Libraries in Context; Social, Cultural and Intellectual Background', in Cambridge History of Libraries in Britain and Ireland Volume II 1640-1850, ed. Giles Mandelbrote and K. A. Manley (Cambridge: Cambridge University Press, 2006), 285-300 (285).

26. South Australian Register (Adelaide), June 20, 1848, 2.

27. Bendigo Advertiser, January 10, 1865, 2.

28. South Australian Register, August 22, 1856, 2. See also South Australian Register, August 30, 1856, 6.

29. Singapore Free Press and Mercantile Advertiser, September 21, 1843, 2.

30. F. M. Bladen, Public Library of New South Wales: Historical Notes, 2nd ed. (Sydney: Govt. Printer, 1911), esp. 8-41.

31. Wallace Kirsop, 'Libraries for an Imperial Power', in Cambridge History of Libraries in Britain and Ireland Volume II 1640-1850, ed. Giles Mandelbrote and K. A. Manley (Cambridge: Cambridge University Press, 2006), 494-508 (496-97).

32. South Australian Register, November 29, 1848, 2. See also Adelaide Times, September 13, 1851, 5 .

33. Catalogue, SAPL, 1842, v: http://www.ucd.ie/southhem/record. html\#269.

34. Catalogue, MPL, 1861, vi: http://www.ucd.ie/southhem/record. html\#112.

35. David McVilly, "Something to Blow About"?-the State Library of Victoria, 1856-1880', La Trobe Journal 8 (1971): 81-90 (82).

36. Quoted in Wallace Kirsop, 'Redmond Barry and the Libraries', La Trobe Journal 73 (2004): 55-66 (64-65).

37. Kirsop, 'Redmond Barry and the Libraries', 65.

38. Catalogue, SAPL, 1829: http://www.ucd.ie/southhem/record.html\#264; Catalogue, SAPL, 1831: http://www.ucd.ie/southhem/record.html\#265; Catalogue, SAPl, 1837: http://www.ucd.ie/southhem/record.html\#268; Catalogue, SAPL, 1848: http://www.ucd.ie/southhem/record.html\#464.

39. Singapore Library Report 1845, 6-7. 
40. Straits Observer (Singapore), May 3, 1875, 21. Straits Settlements Annual Reports for the Year 1874 (Singapore: Government Printing Office 1875), 121-122.

41. Catalogue, ASL, 1839, 22: http://www.ucd.ie/southhem/record.html\#30; Catalogue, ASL, 1843, 24: http://www.ucd.ie/southhem/record.html\#33; Catalogue, ASL, 1853, n.p.: http://www.ucd.ie/southhem/record. html\#520.

42. Sydney Morning Herald, May 26, 1871, 5.

43. Catalogue, TPL, 1849, vi: http://www.ucd.ie/southhem/record. html\#480; Catalogue, TPL, 1852, ix: http://www.ucd.ie/southhem/ record.html\#327; Catalogue TPL, 1855, xi: http://www.ucd.ie/southhem/record.html\#312; Catalogue, TPL, 1862, 11: http://www.ucd.ie/ southhem/record.html\#482.

44. Catalogue, TPL, 1871, 6: https://trove.nla.gov.au/goto? $\mathrm{i}=\mathrm{x} \& \mathrm{w}=35488$ 264\&d=http\%3A\%2F\%2Fhandle.slv.vic.gov.au\%2F10381\%2F200582\&s =fMgPfYTpRceruXgITlGoh01SWTRn7GoWlmLBl9P3UCQ\%3D.

45. Adelaide Observer, September 27, 1856, 1. South Australian Register, November 29, 1848, 2; October 13, 1869, 2.

46. Melbourne Punch, July 14, 1859, 3.

47. Catalogue, SAPL, 1848, 13: http://www.ucd.ie/southhem/record. html\#464.

48. Marvin Spevack, 'The Impact of the British Museum Library', in Cambridge History of Libraries in Britain and Ireland Volume II 16401850, ed. Giles Mandelbrote and K. A. Manley (Cambridge: Cambridge University Press, 2006), 422-437 (435).

49. The South Australian Institute: Comprising the Public Library, Art Gallery, and Museums. Addresses Delivered at the Laying of the Foundation Stone (Adelaide: W. K. Thomas, 1879), 8.

50. Herald (Melbourne), September 20, 1874, 2. See also Herald, March $28,1862,4$.

51. Herald, December 5, 1876, 2.

52. Elizabeth Morrison, 'The Archaeology of Australian Colonial Newspapers', in Australian Serials: Current Developments in Bibliography, ed. Carol Mills and John Mills (New York: Haworth Press, 1991), 35-51 (46); R. C. Barrington Partridge, The History of the Legal Deposit of Books Throughout the British Empire (London: Library Association, 1938), 157-167.

53. Singapore Free Press and Mercantile Advertiser, August 24, 1843, 2.

54. C. B. Buckley, An Anecdotal History of Old Times in Singapore, 2 vols (Singapore: Fraser and Neave, 1902), 1: 442.

55. New Zealand Journal, July 13, 1844, quoted in Traue, 'The Public Library Explosion', 159. 
56. Singapore Library Report 1849 (Singapore: G. M. Frederick at the Singapore Press Office, 1849), 9. See also Brendan Luyt, 'Centres of Calculation and Unruly Colonists: The Colonial Library in Singapore and its Users, 1874-1900', Journal of Documentation 64, no. 3 (2008): 386-396 (390).

57. Straits Observer, December 28, 1874, 2.

58. Catalogue, SAPL, 1848, 13: http://www.ucd.ie/southhem/record. html\#464.

59. Catalogue, SAPL, 1842, iii: http://www.ucd.ie/southhem/record. html\#269. On the affective meanings of 'home', see Jason R. Rudy, Imagined Homelands: British Poetry in the Colonies (Baltimore: Johns Hopkins University Press, 2017), 6.

60. Catalogue, SAPL, 1848, 7-8: http://www.ucd.ie/southhem/record. html\#464.

61. Catalogue, SAPL, 1853, 8-17: http://www.ucd.ie/southhem/record. html\#469.

62. Sue Reynolds, 'Libraries, Librarians, and Librarianship in the Colony of Victoria', Australian Academic and Research Libraries 40, no. 1 (2013): 50-64 (59).

63. See Redmond Barry's connection between public libraries and a 'confederating' sentiment in his Address on the Opening of The Free Public Library of Ballarat East by Sir Redmond Barry (Ballarat: The Star Office, 1869), $5,6,22$.

64. South Australian Register, August 12, 1854, 3.

65. South Australian Register, April 20, 1858, 3.

66. Catalogue, SAPL, 1857, 5: http://www.ucd.ie/southhem/record. html\#471.

67. Catalogue, SAPL, 1853, 19: http://www.ucd.ie/southhem/record. html\#469. For contemporary complaints about Chetham's access hours, see Edwin Waugh, Lancashire Sketches (Frankfurt Am Main: Outlook Verlag, 2018), 222.

68. Lewis C. Roberts, 'Disciplining and Disinfecting Working-Class Readers in the Victorian Public Library', Victorian Literature and Culture 26, no. 1 (1998): 105-132 (106).

69. 'Cape of Good Hope Public Library', Mechanics' Magazine, Museum, Register, Journal and Gazette 25 (1836): 222-223 (222). Robert Montgomery Martin, History of the Colonial Library, Vol. 3: History of South Africa (London: Whitaker \& Co., 1836), 207.

70. Argus (Melbourne), January 2, 1860, 6.

71. Times (London), October 16, 1841, 5.

72. Joyce, 'Politics of the Liberal Archive', 41.

73. Argus, July 6, 1855, 5 . 
74. ASL, Minutes and Proceedings, 1826-1846, October 12, 1829, Australian Library and Literary Institution Papers, 1826-1871, Manuscript, State Library of New South Wales, Al625.

75. Catalogue, MPL, 1861, viii: http://www.ucd.ie/southhem/record. html\#112.

76. Quoted in Richard Overell, 'The Melbourne Public Library and the Guillaumes: The Relations between a Colonial Library and its London Book Supplier, 1854-1865', in Peopling a Profession: Papers from the Fourth Forum on Australian Library History, ed. Frank Upward and Jean P. Whyte (Melbourne: Ancora Press, 1991), 33-63 (43).

77. For the figure of 650 seats, see McVilly, "'Something to Blow About"?', 82. P. R. Harris, 'The British Museum Library 1857-1973', in The Cambridge History of Libraries in Great Britain and Ireland Volume III 1850-2000, ed. Alistair Black and Peter Hoare (Cambridge: Cambridge University Press, 2006), 281-298 (282).

78. Barry, Address on the Opening of The Free Public Library of Ballarat East, 16-18.

79. Geoffrey Sherington, Australia's Immigrants 1788-1978 (Sydney: George Allen \& Unwin, 1980), 59; James Belich, Replenishing the Earth: The Settler Revolution and the Rise of the Angloworld (Oxford: Oxford University Press, 2009), 309-312.

80. For a similar view of New Zealand's progress, see J. E. Traue, 'A Paradise for Readers? The Extraordinary Proliferation of Public Libraries in Colonial New Zealand', Script \& Print: Bulletin of the Bibliographical Society of Australia and New Zealand 29 (2005): 323-340 (332).

81. Straits Times, September 30, 1846, 3.

82. David Goodman, Gold Seeking: Victoria and California in the 1850s (Stanford: Stanford University Press, 1994), 87.

83. Herald (Melbourne), March 28, 1862, 4.

84. South Australian Weekly Chronicle (Adelaide), September 2, 1866, 4.

85. Argus, July 14, 1855, 4.

86. Argus, October 27, 1856, 2.

87. The South Australian Institute... Addresses Delivered at the Laying of the Foundation Stone, 17.

88. Joyce, 'Politics of the Liberal Archive', 44.

89. South Australian Register, October 18, 1859, 5.

90. See, for example, South Australian Register, September 7, 1859, 3.

91. Joyce, 'Politics of the Liberal Archive', 42.

92. On the loggia design, see Argus, July 6, 1855, 5, and Brian Hubber, 'Leading by Example: Barry in the Library', La Trobe Journal 73 (2004): 67-74 (68-69). 
93. Argus, September 10, 1866, 6. See also Redmond Barry, Address to the Workmen Employed in Building the Great Hall of the Melbourne Public Library and Museum in Melbourne, Victorian (Melbourne: Wilson \& Mackinnon, 1866).

94. Bain Attwood and Helen Doyle, Possession: Batman's Treaty and the Matter of History (Carlton, Vic: Miegunyah Press, 2009), 134.

95. Catalogue, SAPL, 1829: http://www.ucd.ie/southhem/record.html\#264.

96. Catalogue, SAPL, 1842: http://www.ucd.ie/southhem/record.html\#269.

97. Catalogue, SAPL, 1862: http://www.ucd.ie/southhem/record.html\#270.

98. Straits Times, September 30, 1846, 3.

99. General Catalogue of Bound Volumes in the Raffles Library, September 1, 1877 (Singapore: s.n., 1877), n.p.

100. Gaunt, 'Identity and Nation in the Australian Public Library', 33, 43-51.

101. South Australian Weekly Chronicle, October 19, 1861, 3.

102. Catalogue, SALMI, 1848: http://www.ucd.ie/southhem/record.html\#49; Catalogue, SAI, 1869: http://www.ucd.ie/southhem/record.html\#188.

103. Heather Gaunt, "To do things for the good of others": Library Philanthropy, William Walker, and the Establishment of the Australiana Collection at the Tasmanian Public Library in the 1920s and 1930s', The Australian Library Journal 56, no. 3/4 (2007): 251-264.

104. Gaunt, 'Identity and Nation in the Australian Public Library', 43-45.

105. See G. D. Richardson, 'Mitchell, David Scott (1836-1907)', ADNB, accessed 14 November 2018: http://adb.anu.edu.au/biography/ mitchell-david-scott-4210.

106. Graeme Johanson, A Study of Colonial Editions in Australia, 1843-1972 (Wellington: Elibank Press, 2000).

107. Quoted in Gaunt, 'Identity and Nation in the Australian Public Library', 44.

108. Herald, September 20, 1874, 2; Austral Review, Aug 1877, 2; Age, January 27, 1879, 2. See McVilly, "“Something to Blow About”?", 87.

109. John Dunham, 'The British India Holdings of the State Library of Victoria', La Trobe Journal 16 (1975): 77-88 (78, 81).

110. Dunham, 'British India Holdings', 84.

111. Herald, August 21, 1861, 5.

112. Argus, June 26, 1867, 7.

113. Dunham, 'British India Holdings', 77. 
Open Access This chapter is licensed under the terms of the Creative Commons Attribution 4.0 International License (http://creativecommons.org/licenses/ by $/ 4.0 /$ ), which permits use, sharing, adaptation, distribution and reproduction in any medium or format, as long as you give appropriate credit to the original author(s) and the source, provide a link to the Creative Commons licence and indicate if changes were made.

The images or other third party material in this chapter are included in the chapter's Creative Commons licence, unless indicated otherwise in a credit line to the material. If material is not included in the chapter's Creative Commons licence and your intended use is not permitted by statutory regulation or exceeds the permitted use, you will need to obtain permission directly from the copyright holder. 